\title{
Exploration on the Feasibility of Opening Art Practice Course in Dance Major of Colleges and Universities
}

\author{
Ying Hui \\ Shaanxi Normal University, Xi'an Shaanxi, 710000, China
}

Keywords: Colleges and universities, Dance major, Opening, Art practice course, Feasibility

\begin{abstract}
During the teaching process of dance major, colleges and universities emphasize to improve students' practical ability, guarantee the improvement of students' art practical ability through opening art practice course for the dance major. While the feasibility of opening art practice course for the dance major still needs verification. Therefore, this paper chooses the 300 dance major students of the dancing college of South China Normal University as study object and use multiple methods to study the feasibility of opening art practice course for dance major in colleges and universities, investigate and survey its artistic value, have a further understanding on dance art and propose measures to strengthen the art practice education to improve the teaching quality of dance major of colleges and universities during the analysis process.
\end{abstract}

\section{Introduction}

With a long history, our country not only has abundant cultural heritage, the scientific and technical level has also been improved continuously. At present, in the international competition, not just the competition of scientific, technical and economic strength, but also the competition of national spirit and national culture, during the competition of spiritual civilization level, our country has to improve students' comprehensive quality, especially improve the quality of dance education. As the key point of art education, dance art spread further level of emotion for human, and expresses people's yearn for truth, kindness and beauty, therefore, opening the teaching process of dance major, colleges and universities have to optimize teaching mode, opening art practice course in the colleges and universities to make dance education can comply with the development of society. In order to acquire good effect of dance education, it is necessary to make research on the feasibility of opening art practice course to provide theoretical basis for the dance education in the colleges and universities.

\section{Research objects and methods}

\section{Research objects.}

This paper chooses the 300 dance major students of the dancing college of South China Normal University as study object to analyze the feasibility of opening art practice course for these 300 students, the dance skill differences of the 300 students are not obvious, among which, with 150 male students, 150 female students, $\mathrm{P}>0.05$, with comparability.

\section{Research methods.}

During the analysis process of the feasibility of opening art practice course for dance major of dancing college of the South China Normal University, following methods are used for research: firstly, method of documentary. Researchers collect and read related materials on dance, education and aesthetics to make feasibility analysis for opening art practice course for colleges and universities. Secondly, questionnaire method. This investigation totally released 300 questionnaires and collected back 297 of them, with 3 invalid questionnaires, thus total had 294 real effective questionnaires, recovery rate and effective recovery rate are respectively $99 \%$ and $98 \%$. Thirdly, individual interviews. Interview relevant experts and teachers and students on related questions on opening art practice course for colleges and universities to discuss its feasibility. Fourthly, mathematical statistics. Process data of this survey through using the SPSS statistical software. 


\section{Result and analysis}

\section{Student's recognition degree for opening dance art practice course.}

This research used the above mentioned methods to study the feasibility of opening art practice course for dance major of South China Normal University, analyzed the 300 students' recognition degree on opening dance art practice course, then determine the its feasibility ${ }^{[1]}$. Compare recognition degree of male students and female students, among the 294 valid questionnaires, there are 145 questionnaires from male students, 149 from female students, they respectively thought it is very necessary, necessary, not to matter, no need to opening dance art practice course. There are 60 (41\%) male students and 82 (55\%)thought it is necessary to open art practice course,65 (45\%) male students and 70 (50\%)thought it is necessary to open art practice course for the dance major, while 95(65.5\%) male students and 98(66\%)thought it is not matter to open art practice course for dance major of the colleges and universities. Besides, 5(3\%) male students and 2(1.3\%)thought it is no need to open art practice course.

From this research we know that there are obvious different opinions on opening art practice course for dance major, among which, the number of male students who thought it is not matter is more than that of female students ${ }^{[2]}$. While from the whole survey result, most of students agree to open art practice course in South China Normal University, small part of students keep a neutral and negative attitude, of course, there are also a small part of students who have little understanding on the art practice course, which was caused by their lacking of dance, on a certain content, the feasibility to open art practice course in colleges and universities is very big.

\section{Recognition degree on the artistic value of dance of different students}

Through this analysis process, for the question that dance art practice course can adjust psychological effects, students' answers are respectively yes, do not know, no ${ }^{[3]}$. Among the 294 valid questionnaires, 132 (45\%)male thought it can adjust psychological effects, 12(4\%)male thought it cannot adjust psychological effects;15(5\%)don't know, 8(2.7\%) thought it cannot adjust psychological effects.

Survey result showed that students have obviously different opinions on the question that opening art practice course for dance major can adjust psychological effects. However, major of the the chose 300 dance students though it can adjust psychological effects. During the interview with these who agree this, students expressed that when they listened a beautiful music in the dance class and under the environment of art practice, they can combine movements with music perfectly, thus their mood will change accordingly, annoyance will go way and their body can get relaxed. Therefore, students' recognition degree on the artistic value of dance is pretty high ${ }^{[4]}$.

\section{Students' likeness on dance art practice course.}

From the comparison of the likeness of male and female students on opening art practice course for dance major, there are 98(68\%)male students like art practice course very much, 120(81\%)female students like it very much, 100(69\%)male students like art practice course, 99(66\%) like it, 85(59\%) male students normally like it, 90(60.4\%) female students normally like it, 55(38\%)male students don't like opening art practice course, 53(36\%)don't like it.

Through the survey result, students' likeness degree on opening art practice course for dance major is obviously different. Secondly, compared with male students, likeness degree of female students is higher than that of male students. From students' interview we can see that influenced by the education environment, living environment and characteristics, their likeness degree are different. However, part of students still thought it is feasible to open art practice course for dance major.

\section{Conclusion and Suggestions}

\section{Conclusion.}

The research result showed that most of the students opt to open art practice course and thought it has important function on adjusting psychological effects. Therefore, in the dance teaching process, 
colleges and universities should strengthen their teaching efforts on art practice course ${ }^{[5]}$. Because of the different living environment and education environment, students' likeness degree on dance art and opening art practice course are different, but from the whole, most of the dance major students like dance art, therefore, they agree to open art practice course, especially the female students thought it is very necessary, thus from this survey, we can see that opening art practice course lays an important foundation for the sustainable development of professional dance teaching of colleges and universities.

Besides, this survey showed that different students have different opinions on the artistic value of dance, compared with the students who did not attend art practice course, those who attended this course have a higher recognition degree and thought it is necessary to open art practice course. This shows that as a kind of aesthetic form in the society, dance has an unique form, the truth, kindness and beauty can be found directly through it, thus opening art practice course in the colleges and universities can optimize their learning, improve their comprehensive quality, thus it is feasible and necessary to open art practice course in colleges and universities, it has an important effect on improving dance teaching in colleges and universities.

\section{Suggestions.}

Through this survey we can find that though there are many students agree to open art practice course for dance major of colleges and universities, while there are still part of students don't like it. Therefore, in order to further improve dance teaching quality, colleges and universities have to strengthen the propaganda work of dance art, help students and teachers have a full understanding on dance and learn the essence of art practice course through taking effective measures, thus to realize the good development of dance major, make survey on the art practice course for students, fully grasp students' dynamic and psychological changes, then improve the teaching method of dance major to motivate students' interest on art practice course and dance by combining survey result and taking countermeasures.

\section{Methods for dance major in colleges and universities to open art practice course effectively}

\section{Make a scientific teaching plan for the art practice course of dance major.}

During the dance teaching process, in order to effectively open art practice course, colleges and universities have to make a scientific teaching plan for the art practice course of dance major thus teachers carry out teaching activities according to the thorough plan to improve students' artistic practical ability.

Therefore, colleges and universities should combine students' learning regulation and development direction of students in different grades and the art practice concept to make a perfect teaching plan. Meanwhile, under the guidance of the teaching programme to choose the representative dance performance course, during the teaching process, students in dance major should pay more attention to the learning of performance skill, improve their review ability and practice ability through imitation. Besides, the art practice course must have penetrability, teachers should classify and guide students based on the characteristics of students in different grades. At the same time, teaching plan of the art practice course should not be short-term teaching activities, but to make students gradually learn in the whole learning process through long-term activities, students in lower grades should improve regulate their art practice sense, students in higher grades should combine theory and practice. In a word, make scientific teaching plan for art practice course of dance major to guarantee the obvious improvement of students' dance art practice.

\section{Often participate in dance art practice activities.}

Colleges and universities must strictly carry out the scientific teaching plan of art practice course for dance major to guarantee the full play of the opened art practice course of dance major. Therefore, teachers should strengthen the teaching efforts on art practice course during the teaching process of dance major, help students to express the aritisic value of dance in class through theater creation and graduation performance. Besides, colleges and students should provide students with practical opportunities. For example, arrange students to make dance performance for enterprises and public 
institutions during winter holiday. Or improve students' practice ability of dance art through taking part in literary and artistic activity to help students improve dance art practice ability in practice.

\section{Conclusion}

During the spiritual civilization, colleges and universities should strengthen education, pay more attention to the mission of dance teaching, relocate art practical work through changing traditional teaching concept to make the dance major teaching achieve a good result. During its emphasis on art practice, colleges and universities should make feasibility analysis for opening art practice course for dance major, then take effective measures to strengthen the art practice teaching to guarantee students' extension and comprehensive quality. In short, colleges and universities should realize the importance of opening art practice course, and deepen the artistic roots of dance major through constant efforts.

\section{References}

[1] Wang Liyan. Thinking on Opening Art Practice Education for Dance Major in Colleges and Universities. Journal of Qilu Normal University,2012,27(3):150-153.

[2] Chen Yaxian. Pan Yanna. Discussion on Creating New Training Mode for Music and Dance Art Talents. Journal of Guangzhou University: JCR Social Science Edition,2012,11(5):66-70.

[3] Zhang Xiaohong. Discussion on the Remains of Regional Folk Dance Culture--Features in the Application Teaching. Theoretical Observation,2014(8):102-103.

[4] Yi Guannan. Research on the Choreographer Theory and Practical Course Teaching of Performance Major of Colleges and Universities. The Asia-pacific Education,2015(32):215.

[5] Liu Hanbing. Discussion on the Strategy for Improving Dance Appreciation Level of Students in Dance Major.. Grand Sight,2015(6):138-138. 